\title{
Prevalence and Genotype Distribution of High-risk Human Papilloma Virus Types Compared with Cervical Cytology
}

\author{
Yüksek Riskli Human Papilloma Virüs Genotiplerinin Prevalansı, Dağılımı ve Servikal Sitoloji \\ Sonuçları ile Karşılaştııılması
}

\author{
(1) Selin UĞRAKLI ${ }^{1}$, (1) Mehmet ÖZDEMiR ${ }^{2}$, (1) Yasemin Derya GÜLSEREN ${ }^{3}$, (1) Sıddıka FINDIK ${ }^{4}$ \\ ${ }^{1}$ Konya Directorate of Public Health, Public Health Laboratory, Department of Microbiology, Konya, Turkey \\ ${ }^{2}$ Necmettin Erbakan University Meram Faculty of Medicine, Department of Medical Microbiology, Division of Medical Virology, Konya, Turkey \\ 3 Ministry of Health Balıkesir Atatürk City Hospital, Clinic of Medical Microbiology, Division of Medical Virology, Balıkesir, Turkey \\ ${ }^{4}$ Necmettin Erbakan University Meram Faculty of Medicine, Department of Pathology, Konya, Turkey
}

\section{Abstract}

Introduction: Human papilloma virus (HPV) is a well-known causative pathogen of cervical cancer. The distribution of HPV prevalence and genotypes differ between regions. This study aimed to detect the prevalence of high-risk HPV (hrHPV) and genotype distribution among patients with cervical cytology.

Materials and Methods: A total of 1,571 women aged 17-91 years who presented to the department of Gynecology and Obstetrics Outpatient Clinic of our hospital, between January 1, 2017, and July 30, 2019, were included. Samples were collected for cytology and transported to the Medical Microbiology Laboratory for HPV deoxyribonucleic acid (DNA) test. Cervical specimens were investigated for the presence of hrHPV and genotyping of HPV using a commercial kit (Nuclear Laser Medicine S.r.l., Milano, Italy) by real-time polymerase chain reaction. Simultaneously, cytological examination was performed using conventional (Papanicolaou) method and interpreted according to the Bethesda system. Data were analyzed using the Statistical Package for the Social Sciences (SPSS) version 22.0 (SPSS Inc., Chicago, IL, USA).

Results: Of the 1,571 women with a mean age of $39.98( \pm 10.17)$ years, HPV DNA was negative in $972(61.9 \%)$ patients, while $599(38.1 \%)$ patients were positive for hrHPV. No significant difference was found between age groups in terms of HPV positivity $(p=0.18)$. The most common hrHPV types detected were HPV16 (28.5\%), HPV68 (18.7\%), HPV51 (15.5\%), HPV39 (15.4\%), and HPV31 (13.4\%), in descending order. Single HPV infections were found in 61.4\% (368/599), while infections with multiple HPV genotypes were detected in 38.6\% (231/599) of all cases.

Conclusion: This study indicated that HPV infection is more prevalent than expected among women living in the central part of Turkey. Additionally, the high prevalence of non-vaccinable genotypes should be considered a regional difference, and the use of this knowledge for guidance in the selection and development prophylactic vaccines may lead to successful broader prevention.

Keywords: HPV, screening, vaccine, cancer

\section{Öz}

Giriş: Human papilloma virüs (HPV), servikal kanser gelişimi açısından iyi bilinen bir etken patojendir. Human papilloma virüs prevalansı ve genotiplerinin dağılımı bölgeler arası değişkenlik göstermektedir. Bu çalışmanın amacı, servikal sitolojisi olan hastalarda yüksek riskli HPV (YR-HPV) prevelansını ve genotip dağılımını tespit etmektir.

Gereç ve Yöntem: 1 Ocak 2017-30 Temmuz 2019 tarihleri arasında hastanemizin Kadın Hastalıkları ve Doğum Polikliniği'ne başvuran 17-91 yaşları arasında toplam 1.571 kadın dahil edildi. Servikal sitoloji için numuneler toplandı ve HPV deoksiribonükleik asit (DNA) testi için Tıbbi Mikrobiyoloji

Cite this article as: Uğrakı S, Özdemir M, Gülseren YD, Findık S. Prevalence and Genotype Distribution of High-risk Human Papilloma Virus Types Compared with Cervical Cytology. Mediterr J Infect Microb Antimicrob. 2021;10:27 
Laboratuvarı'na gönderildi. Servikal numuneler YR-HPV varlığı ve genotiplendirilmesi için gerçek zamanlı polimeraz zincir reaksiyonu ile ticari bir kit (Nuclear Laser Medicine S.r.l., Milano, İtalya) kullanılarak araştırıldı. Eş zamanlı olarak sitolojik inceleme, geleneksel (Papanicolaou) yöntem kullanılarak yapıldı ve Bethesda sistemine göre yorumlandı. Veriler Statistical Package for the Social Sciences (SPSS) sürüm 22.0 (SPSS Inc, Chicago, IL, ABD) kullanılarak analiz edildi.

Bulgular: Çalışmaya ortalama yaşı 39,98 $( \pm 10,17)$ olan 1.571 kadın hasta dahil edildi. Hastaların 972'sinde $(\% 61,9)$ HPV DNA negatif iken; 599 $(\% 38,1)$ hastada YR-HPV pozitif olarak bulundu. Yaş grupları arasında HPV pozitifliği açısından anlamlı fark bulunmadı ( $p=0,18)$. Tespit edilen en yaygın YR-HPV tipleri azalan sıra ile HPV16 $(\% 28,5)$, HPV68 $(\% 18,7)$, HPV51 $(\% 15,5)$, HPV39 $(\% 15,4)$ ve HPV31 (\%13,4) idi. Tüm pozitif sonuçların \%61,4'ünde (368/599) tek tip HPV genotipi ile enfeksiyon tespit edilirken; \%38,6'sında (231/599) multipl enfeksiyon saptandı.

Sonuç: Bu çalışmada Türkiye'nin merkezi kısmında yer alan bir bölgedeki kadınlarda HPV prevalansı beklenenden daha yüksek olarak saptandı. Ek olarak, bu çalışmada aşı dışı genotiplerin yüksek prevalansı bölgesel bir farklılık olarak düşünülmelidir. Bu bilgilerin profilatik aşıların seçiminde ve geliştirilmesinde rehberlik amacıyla kullanılması daha geniş bir koruma sağlayabilir.

Anahtar Kelimeler: HPV, tarama, aşı, kanser

\section{Introduction}

Cervical cancer is one of the most common cancer considered as the major cause of cancer-related death among women worldwide ${ }^{[1]}$. Currently, persistent infection with carcinogenic human papilloma virus (HPV) genotypes is the main etiologic agent for cervical cancer ${ }^{[2]}$. Women are at higher risk for HPV-related cancers. However, men with high-risk behaviors (unprotected sexual intercourse, men who have sex with men, multiple sexual partners etc.) are dramatically at a higher risk for developing HPV-associated cancers, particularly anal cancer ${ }^{[3]}$. Recent studies have also reported on the role of HPV-related carcinogenesis in oropharyngeal, head, and neck cancers $^{[2]}$. Human papilloma viruses are a diverse group of small, non-enveloped, double-stranded deoxyribonucleic acid (DNA) viruses that tend to show an exclusive tropism, affecting mucosal and cutaneous squamous epithelia ${ }^{[4]}$. Although HPV infection is the most common sexually transmitted viral disease, it is frequently reversed by defense of the host immune system $^{[5]}$. Approximately, 90\% of women with HPV infection were determined to have viral clearance by a competent cellmediated immune response. Although the duration of infection may vary according to HPV types, the average time to clearance is 6-18 months ${ }^{[5]}$. To date, more than 200 HPV genotypes have been identified. However, only 40 of them are associated with the anogenital tract. These types are divided into high- and lowrisk types based on their oncogenic potential. High-risk HPV (hrHPV) types 16, 18, 31, 33, 35, 39, 45, 51, 52, 56, 58, and 59 have been observed in 99\% of cervical cancer cases ${ }^{[6,7]}$. HPV16 is the most common type related to carcinogenesis, followed by HPV18. Therefore, available prophylactic HPV vaccines include the two common oncogenic types, which are responsible for nearly $70 \%$ all cervical cancer cases globally ${ }^{[6,7]}$. Although HPV vaccines indicate a significant clinical development in cancer prevention, various additional considerations need to be improved to optimize vaccine efficiency. The high cost of these vaccines limit their widespread implementation in lowresource countries ${ }^{[8]}$. Moreover, these vaccines do not cover all oncogenic HPV types ${ }^{[6,9]}$. Because of the limitations related to
HPV vaccines, cervical cancer screening tests are still significant for short-term cancer prevention strategies.

Owing to the successful implementation of national HPVbased screening programs, which have already became an indispensable part of cancer prevention policies, cervical cancer incidence has been decreasing gradually. The screening of precancerous lesions and cervical cancer was initiated through single Papanicolaou (Pap) smear test, which has high false-negative results. Human papilloma virus DNA testing was incorporated into cytology tests, and co-testing with Pap smear and hrHPV typing demonstrated a higher success ratio ${ }^{[10,11]}$.

This study aimed to investigate the prevalence of hrHPV DNA and the association of cervical cytology with HPV genotypes in women who presented to our hospital.

\section{Materials and Methods}

This study analyzed the HPV status and cervical cytology test results of 1,571 patients who presented to the department of Gynecology and Obstetrics Outpatient Clinic at our hospital, between January 1, 2017, and July 30, 2019. Patients' data were obtained from the hospital electronic record. The study was apporoved by the Research Ethics Committee of Necmettin Erbakan University, Konya, Turkey (decision protocol number: 2020/2914, dated: November 20 2020). Because this was a retrospective laboratory record-based study, informed consent was not received.

Cervical swab samples were collected in women suspected with HPV infection and sent to the Department of Molecular Laboratory of Medical Microbiology to perform molecular test for HPV DNA detection and genotyping assays. After processing of samples, DNA was extracted using a magnetic bead technology (EZ1 Virus Mini Kit v.2.0, Germany). Real-time polymerase chain reaction (PCR) was performed using the HPV Genotype 14 Real-Time Quant Kits (Nuclear Laser Medicine S.r.l., Milano, Italy) for detection and genotyping of HPV types (HPV16, 18, 31, 33, 35, 39, 45, 51, 52, 56, 58, 59, 66, and 68) on the Rotor-Gene 0 pplex HRM instrument (Qiagen, Hilden, Germany). The human beta globin gene was used as an internal 
control for material sufficiency, purification, and amplification. Cervical smear samples were taken simultaneously in majority of the patients (1316/1571). Conventionally prepared Pap smears were evaluated by the pathologist. Results were reported according to the Bethesda system nomenclature as follows: atypical squamous cells (ASCUS), atypical glandular cells (AGC), low-grade squamous intraepithelial lesion (LSIL), and highgrade squamous intraepithelial lesion (HSIL).

\section{Statistical Analysis}

In this study, cases were divided into groups according to the HPV test result, presence of single or multiple infections, and all HPV types. Cases were divided into the following age groups: $<25,25-34,35-44,45-54,55-64$, and $\geq 65$ years. In addition, cases were allocated into two age groups: $<35$ years and $\geq 35$ years.

Data were analyzed using the Statistical Package for the Social Sciences (SPSS) version 22.0 (SPSS Inc., Chicago, IL, USA). The results of HPV, HPV types, and cervical smears were analyzed as frequency and percentage. Age data were presented as mean \pm standard deviation. Categorical variables were compared using the chi-square test or Fisher's exact test, and $p<0.05$ was considered significant.

\section{Results}

This study included 1,571 women with a mean age of 39.98 $( \pm 10.17)$ (range, 17-91) years. Human papilloma virus DNA positivity was detected in 38.1\% (599/1571) of all patients. According to the HPV test results, the average age of the patients was $39.8( \pm 10.4)$ years in the HPV DNA positive group and 40.07 $( \pm 10.03)$ in the negative group. Concurrently, histopathological examinations were performed in 1,316 samples, in which were $78(5.9 \%)$ of them had epithelial cellular abnormality. While the median age of women who have any abnormality in the histopathological analysis was $45.37( \pm 12.26)$ years, the average age of patients with normal cytology was $39.97( \pm 9.67)$ years.

When divided into five groups by age, HPV positivity rate was highest in patients aged $>65$ years with 50\%. In addition, majority of HPV-positive results were recorded in women aged 35-44 years (235/599) (Table 1). Therefore, the differences in the age distribution of the study population were also taken into account. Human papilloma virus prevalence was standardized by applying age-specific prevalence estimates. No significant difference was found between age groups in terms of HPV positivity by chi-square test $(p=0.18)$. Similarly, with respect to HPV positivity, no significant difference was found in women aged $<35$ years and $>35$ years $(p=0.4)$. The distribution of HPV genotypes according to age $<35$ years and $>35$ years is shown in Table 2.

The most commonly detected hrHPV genotypes among positive cases were HPV16 (28.5\%), HPV68 (18.7\%), HPV51 (15.5\%), HPV39 (15.4\%), and HPV31 (13.4\%). HPV18 was detected in $7.9 \%$ of the positive cases. Single HPV infections were found in $61.4 \%$ (368/599) of hrHPV-positive cases. Multiple HPV infections were detected in $38.6 \%$ of all patients with hrHPV (Figure 1, Table 2). In 3.5\% of cases with multiple infections, HPV16 and HPV18, which have high oncogenic potential, have been detected together.

In the cytological examination, cellular abnormality was detected in 5.9\% (78/1316) of samples. Cytology tests of 255 study patients were not performed. A total of 1238 (94.1\%) samples were assessed as normal (negative), 65 (4.9\%) as ASCUS, $4(0.3 \%)$ as $\mathrm{LSIL}$, and $3(0.23 \%)$ as HSIL. Human papilloma virus DNA was found in $782(59.4 \%)$ women with normal cytology (Table 3). As regards HPV genotype distribution according to cervical cytology, HPV16 was the most common genotype in

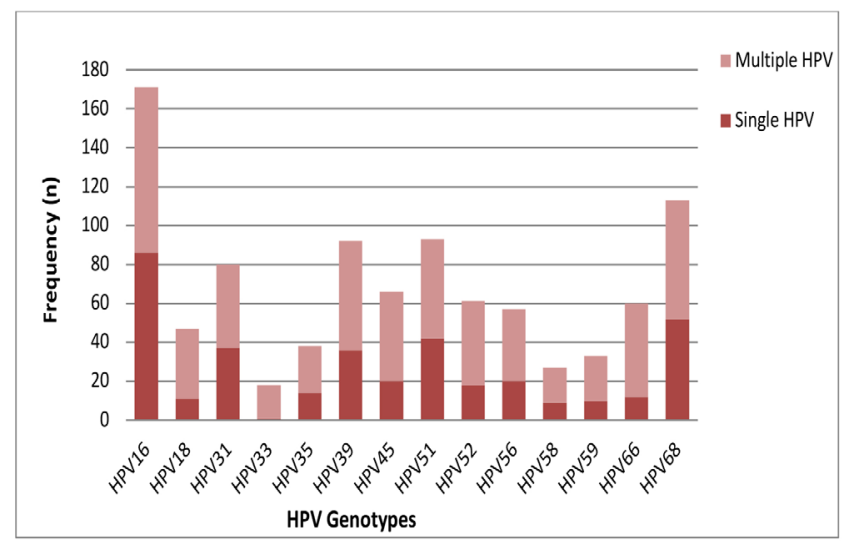

Figure 1. Overall high-risk human papilloma virus genotype patterns indicating the prevalence of single and multiple infections

HPV: Human papilloma virus

Table 1. Distribution of HPV prevalence in the 5-year age group

\begin{tabular}{|c|c|c|c|c|c|c|c|}
\hline & $<25$ & $25-34$ & $35-44$ & $45-54$ & $55-64$ & $>=65$ & Total \\
\hline & n (\%) & n (\%) & n $(\%)$ & n (\%) & n (\%) & n (\%) & n $(\%)$ \\
\hline HPV test negative & $56(62.9)$ & $247(60.1)$ & 351 (59.9) & $230(67.6)$ & $78(62.4)$ & $10(50)$ & 972 (61.9) \\
\hline Total $(p=0.18)$ & 89 & 411 & 586 & 340 & 125 & 20 & 1571 \\
\hline
\end{tabular}

HPV: Human papilloma virus 
cases with and without cytological abnormality (Table 3). In addition, the most common HPV genotype in H-SIL was HPV 16 , which was detected in 100\% (3/3) of cases. Our cytology test results were normal in 126 (73.7\%) of 171 patients with
HPV16, in 20 (42.5\%) of the 47 patients with HPV18, and in 7 (87.5\%) of 8 multiple infections with HPV16 and HPV18. Human papilloma virus DNA test was negative in one patient with LSIL cervical lesion.

\begin{tabular}{|c|c|c|c|}
\hline HPV genotype & $<35$ years & $\geq 35$ years & Total \\
\hline HPV16 & 23 & 63 & 86 \\
\hline HPV18 & 5 & 6 & 11 \\
\hline HPV16 + HPV18 & 1 & 1 & 2 \\
\hline HPV16 + HPV18 + other type* & 2 & 4 & 6 \\
\hline HPV16 + other type & 28 & 49 & 77 \\
\hline HPV18 + other type & 11 & 17 & 28 \\
\hline Multiple infections with more than one HPV other types & 39 & 79 & 118 \\
\hline HPV31 & 10 & 27 & 37 \\
\hline HPV33 & 1 & 0 & 1 \\
\hline HPV35 & 3 & 11 & 14 \\
\hline HPV39 & 16 & 20 & 36 \\
\hline HPV45 & 7 & 13 & 20 \\
\hline HPV51 & 12 & 30 & 42 \\
\hline HPV52 & 4 & 14 & 18 \\
\hline HPV56 & 5 & 15 & 20 \\
\hline HPV58 & 3 & 6 & 9 \\
\hline HPV59 & 4 & 6 & 10 \\
\hline HPV66 & 4 & 8 & 12 \\
\hline HPV68 & 19 & 33 & 52 \\
\hline HPV negative & 303 & 669 & 972 \\
\hline Total & 500 & 1071 & 1571 \\
\hline
\end{tabular}

*0ther type: infection with high-risk HPV type except HPV16 and HPV18.

HPV: Human papilloma virus

Table 3. Human papilloma virus (HPV) distribution across various cervical cytological statuses. The most common HPV types were included in the different cytological lesion

\begin{tabular}{lllll}
\hline & HPV negative & HPV positive & Total & Most common types among HPV-positive cases \\
\hline Normal & 782 & 456 & 1238 & HPV16, HPV68, HPV51, and HPV39 \\
\hline ASCUS & 35 & 30 & 65 & HPV18 and HPV16 \\
\hline AGC & 1 & 2 & 3 & HPV18 and multiple infection with other types \\
\hline ASC-H & 0 & 1 & 1 & HPV31 \\
\hline LSIL & 1 & 3 & 4 & HPV52, multiple infection with other types \\
\hline HSIL & 0 & 3 & 3 & HPV16, multiple infection with HPV16, HPV51, and HPV66 \\
\hline CINIII & 0 & 1 & 1 & Multiple infection with HPV16 and HPV35 \\
\hline CIS $^{+}$ & 0 & 1 & 1 & Multiple infection with HPV16 and HPV51 \\
\hline No cytology & 153 & 102 & 255 & HPV16, HPV68, and HPV31 \\
\hline Total & 972 & 599 & 1571 & \\
\hline ASCUS:Atyin & & &
\end{tabular}

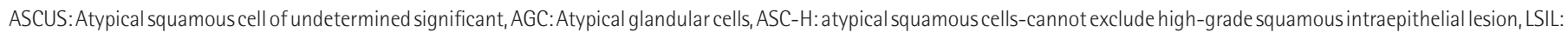

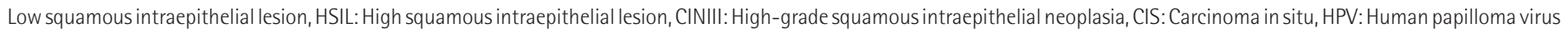




\section{Discussion}

The present study demostrated that HPV infection is more common than expected among women living in the central part of Turkey. 1571 women with a mean age of $39.98( \pm 10.17)$ years were included in this study. Although 599 (38.1\%) patients were positive for hrHPV, HPV DNA was negative in $972(61.9 \%)$ patients. Besides, no significant difference was found between age groups in terms of HPV positivity $(p=0.18)$. The most common hrHPV types determined were HPV16 (28.5\%), HPV68 (18.7\%), HPV51 (15.5\%), HPV39 (15.4\%), and HPV31 (13.4\%), in descending order. Single HPV infections were detected in 61.4\% (368/599), while infections with multiple HPV genotypes were found in 38.6\% (231/599) of all cases. The detected high prevalence of non vaccinable genotypes was found considerable.

Cervical cancer remains a significant public health problem, representing the fourth common cause of cancer incidence and mortality in women globally ${ }^{[1,12]}$. Since the progression time of cervical intraepithelial neoplasia to cervical cancer is slightly extended and as the precancerous lesions can be detected and treated efficiently, cervical cancer is a preventable disease ${ }^{[13]}$. New information has provided future perspective for primary and secondary preventions ${ }^{[13,14]}$. After the application of cervical cytology (Pap smear) test as a cancer screening program, the incidence of cervical cancer has decreased in resource-rich countries. However, the implementation has some limitations ${ }^{[15]}$. Recurrent testing is required to reach an acceptable sensitivity because of the moderate sensitivity (50-70\%) of the single Pap test ${ }^{[13,16,17]}$. Low reproducibility owing to its subjective property is another limitation of Pap smear test ${ }^{[15,16]}$. In recent years, HPV DNA detection and genotyping tests have become increasingly recommended in understanding the role of HPV in cervical cancer development. Previous studies have also shown that 25$50 \%$ of cases that are negative in the Pap smear test can be detected by the HPV DNA test ${ }^{[16]}$.

The prevalence of HPV and genotype distribution varied according to regional and sociocultural differences, selection of the study group, and quality of samples ${ }^{[18,19]}$. Studies from Turkey have reported hrHPV prevalence of $2.4-47.7 \% \%^{[16,18-21]}$. According to Turkey's nationwide HPV screening program, the prevalence of HPV was 3.5\% ${ }^{[22]}$.

In the present study, 38.1\% (599/1571) of the patients were positive for hrHPV, which was higher than the rate reported by majority of other studies from Turkey ${ }^{[19-22]}$. Variations among research results depend not only on geographical differences but also on the characteristics of the study group (hospitalbased or community screening), usage of more sensitive HPV detection methods, and Pap smear findings ${ }^{[20,23]}$. The high HPV prevalence in our study can be explained as follows: This study was designed as hospital-based research and real-time PCR, which is a very sensitive method, was used. In support of our findings, results of previous assays indicated that real-time PCR shows higher clinical sensitivity and specificity than Hybrid Capture 2 ${ }^{[20,24]}$.

In many studies, a higher HPV prevalence was detected in women aged $<35$ years; some of them were found to have newly acquired infection, or reactive latent infection was highly prevalent in the older population ${ }^{[25]}$. According to an extensive cross-sectional study including sexually active women from the general population of 15 areas in 4 continents, particularly in the some of all areas (Netherlands, Argentina, and Mexico), hrHPV positivity rate is significantly higher in women aged $<35$ years ${ }^{[26]}$. In Turkey, Hasberk et al. ${ }^{[27]}$ reported that the rate of HPV DNA detection was higher in women aged $<30$ years. Conversely, in another study in Turkey, Altun et al. ${ }^{[28]}$ presented that the prevalence of HPV DNA was significantly higher in women aged $>30$ years. In this study, patients were divided into five age groups, and no significant difference was found between age groups in terms of HPV positivity ( $p=0.18)$. Additionally, with respect to HPV positivity, no significant statistical difference was found between women aged $<35$ years and $>35$ years $(p=0.4)$.

The worldwide distribution and prevalence of specific HPV genotypes demonstrate variation according to regional differences. For example, according to a study from China detecting HPV prevalence in 51,345 women, the most common hrHPV genotypes were HPV52 (5.05\%), HPV16 (4.76\%), and HPV58 $(2.93 \%)^{[29]}$. In the same study, HPV18 was the sixth most common type. Several previous studies from China have demonstrated that HPV16 is the most common type related to all grades of cytological abnormalities, similar to results reported from Western countries. The same data indicated that HPV52 and HPV58 are considerably common in Chinese women and approximately more common than HPV18, which is inconsistent with the results reported from Western countries ${ }^{[2,30]}$. In the present study, the most common hrHPV types were HPV16 (28.5\%), HPV68 (18.7\%), HPV51 (15.5\%), HPV39 (15.4\%), and HPV31 (13.4\%), in descending order. Similar to results of the present study, worldwide data indicated that HPV16 was the most prevalent genotype in women with/without cytological abnormality. Besides, infection with HPV18 (7.9\%) was more rarely found in our study, similar to a study in Madrid with HPV18 prevalence of $8 \%{ }^{[18]}$. Interestingly, HPV68 was the second most common HPV type detected in the present study, which is different from results of other studies in Turkey and in other countries ${ }^{[18,22-25,29]}$. However, similar to our results, some recent studies have reported increasing prevalence of HPV68 in Korean and Chinese women ${ }^{[29,31]}$. Thus, more studies are needed to clarify the roles of non-vaccinable oncogenic genotypes (HPV68) in cervical cancer pathogenesis and regional variability 
of their prevalence in terms of efficacy and cost-effectiveness for vaccines ${ }^{[31,32]}$.

In this study, as shown in Table 3, over a half (59.4\%) of HPVpositive samples were found in women with normal cytology. Although this ratio is lower in some parts of Europe and Turkey, a study from China showed similar (59.97\%) results ${ }^{[30]}$. This high HPV positivity in cases with normal cytology might be due to early-onset infection with no significant morphological alternation. Patients with HPV infection/negative cytology results continue to have an increased CINIII risk, even when the repeat HPV test is negative ${ }^{[33]}$. Therefore, the recommended screening triage should be performed accurately to provide better clinical management of women with HPV infection/ negative cytology finding.

In the present study, the abnormal cytology rate was 5.9\% (78/1316). This rate was lower than that reported in other studies reported from Turkey ${ }^{[18,23]}$. The possible reason is undocumented cytology test results of 255 of 1571 patients. Owing to the retrospective study design, incomplete follow-up in women with HPV/negative cytology results or inadequate colposcopy referral might induce a low abnormal cytology rate.

HPV genotypes can vary depending on the cytologic diagnostic category. In the normal cytology samples from our study, HPV16 was the most common type (29.2\%), followed by HPV68, 51, and 39. However, in the ASCUS group, HPV18 was the most common high-risk genotype (9.2\%), followed by HPV16 (7.7\%). Akyar et al. ${ }^{[18]}$ reported that HPV16 was the most common highrisk genotype (10.2\%), followed by HPV18 (6.1\%), in cases with normal cytology. Similar to our results, Park et al. ${ }^{[11]}$ found a high prevalence of HPV68 (7.7\%) in the normal cytology group, followed by HPV58 (7.3\%) and HPV16 (6.3\%). Additionally, HPV DNA was detected in cases with AGC, LSIL, HSIL, CINIII, and CIS, which accounted for 66\% 75\%, 100\%, 100\%, and 100\% of the cases, respectively. HPV16 was also the most common type in women with HSIL, CINIII, and CIS.

Owing to the retrospective study design, it was not possible to obtain cytology test findings of some patients. Besides, our results may not exactly indicate general population data because of the limited number of patients, methodological differences, and hospital-based study setting. For this purpose, a greater number of comprehensive, population-based prospective studies are needed.

\section{Conclusion}

This study indicated that HPV infection is more prevalent than expected among women in Turkey. Additionally, HPV68, which is not included in vaccine strains, was the second most common type in this study. As regards vaccination programs, the high prevalence of non-vaccinable genotypes in this study should be considered as a result of regional difference, and using this knowledge for guidance in vaccine selection and development may help in the implementation of primary prevention against cervical cancer.

\section{Ethics}

Ethics Committee Approval: The study was approved by the Research Ethics Committee of Necmettin Erbakan University, Konya, Turkey (decision protocol number: 2020/2914, dated: November 20 2020).

Informed Consent: Since this was a retrospective laboratory record-based study, informed consent was not received.

Peer-review: Externally peer-reviewed.

\section{Authorship Contributions}

Surgical and Medical Practices: S.U., S.F., Concept: S.U., M.Ö., Design: S.U., M.Ö., Data Collection or Processing: S.U., Y.D.G., Analysis or Interpretation: S.U., M.Ö., Y.D.G., Literature Search: S.U., Writing: S.U., M.Ö.

Conflict of Interest: No conflict of interest was declared by the authors.

Financial Disclosure: The authors declared that this study received no financial support.

\section{References}

1. Arbyn M, Weiderpass E, Bruni L, de Sanjosé S, Saraiya M, Ferlay J, Bray F. Estimates of incidence and mortality of cervical cancer in 2018: a worldwide analysis. Lancet Glob Health. 2020;8:e191-203.

2. Kobayashi K, Hisamatsu K, Suzui N, Hara A, Tomita H, Miyazaki T. A review of HPV- related head and neck cancer. J Clin Med. 2018;7:241.

3. Sullivan-Blum Z, Stites S, Kennedy P, Swenson M, Ault K, Alt M, Dietz C, Rotert $\mathrm{P}$, Ramaswamy M. Stakeholder perspectives on linking HIV preexposure prophylaxis with human papillomavirus vaccine. AIDS Patient Care and STDs. 2021;35:65-8.

4. Mac M, Moody CA. Epigenetic regulation of the human papillomavirus life cycle. Pathogens. 2020;9:483.

5. Brianti P, De Flammineis E, Mercuri SR. Review of HPV-related diseases and cancers. New Microbiol. 2017;40:80-5.

6. Ateş $S$, Taşdelen-Öğülmen $D$, Işık ME. The attitudes of parents working in the health sector about their children to be vaccinated for human papilloma virus. Mediterr J Infect Microb Antimicrob. 2020;9:10.

7. Ghittoni $R$, Accardi $R$, Chiocca $S$, Tommasino M. Role of human papillomaviruses in carcinogenesis. Ecancermedicalscience. 2015;9:526.

8. Ladner J, Besson MH, Hampshire R, Tapert L, Chirenje M, Saba J. Assessment of eight HPV vaccination programs implemented in lowest income countries. BMC Public Health 2012;12:370.

9. Barra F, Leone Roberti Maggiore U, Bogani G, Ditto A, Signorelli M, Martinelli

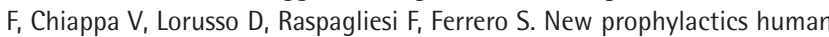
papilloma virus (HPV) vaccines against cervical cancer. J Obstet Gynaecol 2019;39:1-10.

10. Monsonego J, Cox JT, Behrens C, Sandri M, Franco E, Yap PS, Huh W. Prevalence of high-risk human papilloma virus genotypes and associated risk of cervical precancerous lesions in a large US screening population: data from the ATHENA trial. Gynecol Oncol 2015;137:47-54. 
11. Malila $\mathrm{N}$, Leinonen $\mathrm{M}$, Kotaniemi-Talonen, Laurila P, Tarkkanen J, Hakama $M$. The HPV test has similar sensitivity but more overdiagnosis than the Pap test- a randomised health services study on cervical cancer screening in Finland. Int J Cancer. 2013;132:2141-7.

12. Brisson $M$, Kim JJ, Canfell $K$, Drolet $M$, Gingras $G$, Burger $E A$, Martin $D$, Simms KT, Bénard E, Boily M-C, Sy S, Regan C, Keane A, Caruana M, Nguyen DTN, Smith MA, Laprise J-F, Jit M, Alary M, Bray F, Fidarova E, Elsheikh F, Bloem PJN, Broutet N, Hutubessy R. Impact of HPV vaccination and cervical screening on cervical cancer elimination: a comparative modelling analysis in 78 low-income and lower-middle-income countries. Lancet. 2020;395:575-90.

13. Polman NJ, Snijders PJF, Kenter GG, Berkhof J and Meijer CJLM. HPV-based cervical screening: rationale, expectations and future perspectives of the new Dutch screening programme. Prev Med. 2019;119:108-17.

14. Fontham ET, Wolf AM, Church TR, Etzioni $R$, Flowers $C R$, Herzig A, Guerra CE, Oeffinger KC, Tina Shih Y-C,Walter LC, Kim JJ, Andrews KS, DeSantis CE, Fedewa SA, Manassaram-Baptiste D, Saslow D, Wender RC, Smith RA. Cervical cancer screening for individuals at average risk: 2020 guideline update from the American Cancer Society. CA Cancer J Clin. 2020;70:32146.

15. Mayrand MH, Duarte-Franco E, Rodrigues I, Walter SD, Hanley J, Ferenczy A, Ratnam S, Coutlée F, Franco EL, Canadian Cervical Cancer Screening Trial Study Group. Human papillomavirus DNA versus Papanicolaou screening tests for cervical cancer. N Eng J Med. 2007;357:1579-88.

16. Kadıoğlu BG, Tanrıverdi EÇ, Alay H, Uçar M. Relation of Cervical Cancer with the Results of Human Papillomavirus (HPV) Screening Carried out via Hybrid Capture 2 Method on 52.000 Women in Erzurum. Mikrobiyol Bul. 2018;52:367-75.

17. Nanda K, McCrory DC, Myers ER, Bastian LA, Hasselblad V, Hickey JD, Matchar JB. Accuracy of the Papanicolaou test in screening for and followup of cervical cytologic abnormalities: a systematic review. Ann Internal Med. 2000;132:810-9.

18. Akyar I, Aydın Ö, Yakıcıer MC, Kocagöz ZT, Ince Ü, Ünsal i. Human papillomavirus prevalence and type in liquid-based cervical samples from Turkish women in a selected risk group. Turk J Med Sci. 2013;43:963-70.

19. Aydemir Ö, Terzi HA, Köroğlu M, Turan G, Altındiş M, Karakeçe E. Human papillomavirus positivity and genotype distribution in cervical samples. Turk Hij Den Biyol Derg. 2020;77:33-40.

20. Dursun $P$, Senger SS, Arslan $H$, Kuşçu E, Ayhan A. Human papillomavirus (HPV) prevalence and types among Turkish women at a gynecology outpatient unit. BMC Infect Dis. 2009;9:191.

21. Akcali S, Goker A, Ecemis T, Kandiloglu AR, Sanlidag T.Human papilloma virus frequency and genotype distribution in a Turkish population. Asian Pac J Cancer Prev. 2013;14:503-6.

22. Gultekin M, Zayifoglu Karaca M, Kucukyildiz I, Dundar S, Boztas G, Turan HS, Hacikamiloglu E, Murtuza K, Keskinkilic B, Sencan I. Initial results of population based cervical cancer screening program using HPV testing in one million Turkish women. Int J Cancer. 2018;142:1952-8.

23. Aydoğan $S$, Yazgan A,Taş EE, Gözalan A, Yavuz AF, Açıkgöz ZC. The presence and distribution of high risk HPV types in simultaneous cervical cytology samples. Turk Hij Tecr Biyol Derg. 2018;75:13-20.

24. Depuydt CE, Benoy IH, Beert JFA, Criel A M, Bogers JJ, Arbyn M. Clinical validation of a type-specific real-time quantitative human papillomavirus PCR against the performance of hybrid capture 2 for the purpose of cervical cancer screening. J Clin Microbiol. 2012;50:4073-7.

25. Özmen E, Altoparlak Ü, Uyanık MH, Gülen A. Distribution and prevalence of high-risk human papillomavirus genotypes in cervical specimens. FLORA. 2020;25:325-31.

26. Franceschi S, Herrero R, Clifford GM, Snijders PJ, Arslan A, Hoang Anh PT, Bosch FX, Ferreccio C, Hieu NT, Lazcano-Ponce E, Matos E, Molano M, Qiao YL, Rajkumar R, Ronco G, de Sanjosé S, Shin HR, Sukvirach S, Thomas J0, Meijer CJLM, Muñoz N. Variations in the age-specific curves of human papillomavirus prevalence in women worldwide. Int J Cancer 2006;119:2677-84.

27. Hasbek M, Çelik C, Çabuk A, Bakıcı MZ. Frequency and genotype distribution of human papillomavirus in cervical specimens in Sivas Region. Türk Mikrobiyol Cem Derg 2018;48:199-204.

28. Altun Z, Yarkın F, Vardar MA, Uğuz HA. The prevalence of human papillomavirus infection among women who admitted to Cukurova University Faculty of Medicine Hospital. Turkiye Klinikleri J Med Sci 2011;31:307-14.

29. Zeng Z, Yang H, Li Z, He X, Griffith CC, Chen X, Guo X, Zheng B, Wu S, Zhao $C$. Prevalence anf genotype distribution of HPV infection in China: analysis of 51.345 HPV genotyping results from China's largest CAP certified laboratory. J Cancer 2016;7:1037-43.

30. Wang Z, Liu T, Wang Y, Gu Y, Wang H, Liu J, Cui B, Yang X. Risk of cervical lesions in high-risk HPV positive women with normal cytology: a retrospective single-center study in China. Infect Agents Cancer. 2020;15:19.

31. Park E, Kim JY, Choi S, Kim DS, Oh YL. Carcinogenic risk of human papillomavirus (HPV) genotypes and potential effects of HPV vaccines in Korea. Sci Rep. 2019;9:1-9.

32. Halec G, Alemany L, Lloveras B, Schmitt M, Alejo M, Bosch FX, de Sanjose S, Pawlita M. Retrospective International Survey and HPV Time Trends Study Group. Pathogenic role of the eight probably/possibly carcinogenic HPV types 26, 53, 66, 67, 68, 70, 73 and 82 in cervical cancer. J Pathol. 2014;234:441-51.

33. Polman NJ, Veldhuijzen NJ, Heideman DA, Snijders PJ, Meijer CJ, Berkhof J. HPV-positive women with normal cytology remain at increased risk of CIN3 after a negative repeat HPV test. Br J cancer 2017;117:1557-61. 